Jurnal Indonesia Sosial Teknologi: p-ISSN: 2723 - 6609

e-ISSN : 2745-5254

Vol. 2, No. 9 September 2021

\title{
PENGARUH KEBIJAKAN PEMBERLAKUAN PEMBATASAN KEGIATAN MASYARAKAT DARURAT (PPKM) PENGARUH TERHADAP KETAHANAN KELUARGA PEDAGANG DI KEBUMEN
}

\section{Reny Nuraeny ${ }^{1}$, Siti Nur Azizah², Annisa Nur Salam}

MA Salafiyah Wonoyoso Kebumen ${ }^{1}$, Faculty of Islamic Economics and Business, Sunan Kalijaga State Islamic University, Yogyakarta, 55281 Indonesia $^{2}$, Faculty of Islamic Economics and Business, Sunan Gunung Djati State Islamic University, Bandung, 40614, Indonesia $^{3}$

Email: renynuraeny.maskbm@gmail ${ }^{1}$,

\begin{abstract}
Abstrak
Pandemi Covid-19 telah memberikan dampak dari berbagai sisi kehidupan. Pengaruh paling besar yang dirasakan oleh para pedagang di Kebumen ialah adanya kebijakan Pemberlakuan Pembatasan Kegiatan Masyarakat (PPKM). Tujuan dari penelitian ini adalah menganalisis pengaruh kebijakan PPKM terhadap ketahanan keluarga pedagang dari sisi fisik, ekonomi dan ketahanan sosial-psikologisnya. Penelitian ini menggunakan 181 responden pedagang dari 20 area perdagangan di kebumen yang terdiri dari pasar tradisional dan market place. Model penelitian ini merupakan pengembangan dari teori ketahanan keluarga dimana variabel yang digunakan adalah kebijakan PPKM terhadap ketahanan fisik, ekonomi dan sosial-psikologis keluarga pedagang. Metode yang digunakan dalam penelitian ini menggunakan pendekatan kuantitatif dengan analisis deskriptif dan regresi dengan menggunakan metode kuadrat kecil (ordinary least square/ OLS). Hasil penelitian menunjukkan kebijakan PPKM berpengaruh negatif terhadap ketahanan fisik dan ketahanan ekonomi rumah tangga pedagang. Kebijakan PPKM telah memicu terjadinya kerawanan pangan dan ketahanan pangan keluarga, mengikis aktivitas produksi yang berdampak terhadap penurunan omzet dan pendapatan. Namun tidak berpengaruh terhadap ketahanan sosial-psikologi keluarga pedagang karena adanya nilai-nilai sosial yang internalisasi kuat dalam masyarakat mendukung ketahanan sosial-psikologis pedagang di Kebumen.
\end{abstract}

Kata kunci: Covid-19; Kebijakan PPKM; Ketahanan Fisik; Ketahanan Ekonomi; Ketahanan Sosial-Psikologis; Pedagang; Kebumen.

\section{Abstract}

The Covid-19 pandemic has had an impact on various aspects of life. The biggest influence felt by the traders in Kebumen is the policy of the Enforcement of Community Activity Restrictions (PPKM). The purpose of this study was to analyze the effect of the PPKM policy on the resilience of merchant families in terms of physical, economic and socio-psychological resilience. This study uses 181 traders respondents from 20 trading areas in Kebumen consisting of traditional markets and market places. This research model is a development of the theory of family resilience where the variable used is the PPKM policy on the physical, economic and 
socio-psychological resilience of merchant families. The method used in this study uses a quantitative approach with descriptive analysis and regression using the Ordinary Least Square (OLS) method. The results showed that the PPKM policy had a negative effect on the physical and economic resilience of merchant households. The PPKM policy has triggered food insecurity and family food security, eroding production activities which have an impact on decreasing turnover and income. However, it does not affect the socio-psychological resilience of merchant families because of the strong internalized social values in society that support the sociopsychological resilience of traders in Kebumen.

Keywords: Covid-19; PPKM Policy; Physical Resilience; Economic Resilience; SocioPsychological Resilience; Traders; Kebumen

\section{Pendahuluan}

Pandemi covid-19 masih melanda 34 provinsi di Indonesia dan 485 kabupaten/kota di Indonesia. Salah satunya provinsi Jawa Tengah kabupaten Kebumen. Hingga 28 Juni 2021 terdata sebanyak 197 kasus baru sehingga secara akumulatif terdapat 10.212 kasus Covid-19. Sementara itu, kasus aktif bertambah 63 dari 1294 kasus. Kasus sembuh bertambah menjadi 131 pasien sehingga total pasien sembuh sebanyak 8421 orang. Namun kasus meninggal bertambah 7 orang sehingga total pasien meninggal sebanyak 434 orang, pasien dirawat sebanyak 312 dan isolasi mandiri sebanyak 1.045 (Kebumen Tanggap Covid-19). Untuk mengurangi kasus Covid-19 maka pemerintah melakukan kebijakan pemberlakuan pembatasan kegiatan masyarakat Darurat (PPKM Darurat) Khusus di Pulau Jawa dan Bali mulai Sabtu 3 Juli sampai dengan 20 Juli 2021 (KEMENKES, 2021).

Selama masa PPKM Pemerintah membatasi aktivitas penduduk. Pengetatan mobilitas juga berlaku untuk perkantoran, entitas usaha non-sektor esensial, dan kritikal diwajibkan memberlakukan work from home atau bekerja dari rumah untuk seratus persen pegawai. Sedangkan sektor esensial dibatasi dengan kapasitas maksimal lima puluh persen (KEMENKES, 2021). Serta ada tambahan bagi daerah dengan level assesmen 3 dan 4 di Jawa dan Bali terkait target testing, tracing, dan treatment (3T). Selain itu, adanya pengaturan perjalanan dalam penggunaan semua moda transportasi. Pelaku perjalanan baik untuk dinas maupun distribusi barang diwajibkan membawa surat vaksinasi minimal dosis pertama dan hasil tes swab PCR maupun tes antigen yang menunjukkan hasil negatif COVID-19. Bahkan untuk penumpang pesawat, penumpang wajib membawa hasil tes swab PCR 2 x 24 jam. Hal ini untuk mengurangi mobilitas perjalanan antar kota antar provinsi (MENDAGRI, 2021).

Kebumen merupakan kabupaten dengan level assessmen 4. Berdasarkan SURAT EDARAN NOMOR 443/1642, melakukan perpanjangan penerapan PPKM mulai tanggal 24 Agustus 2021 sampai dengan 30 Agustus 2021. Salah satunya kebijakan jam operasional bagi sektor esensial perdagangan seperti supermarket, pasar tradisional, toko kelontong dan pasar swalayan yang menjual kebutuhan primer dibatasi hingga pukul 20.00 WIB dengan kapasitas pengunjung $50 \%$. Pasar rakyat yang menjual barang non kebutuhan sehari-hari dapat beroperasi dengan kapasitas maksimal 50\% dan jam 
operasional sampai pukul 15.00 WIB. Pedagang kaki lima, toko kelontong, pedagang asongan, toko yang tidak menjual kebutuhan sehari- hari dan lain-lain yang sejenis diizinkan buka dengan menerapkan protokol kesehatan ketat sampai dengan pukul 20.00 WIB. Serta pengaturan terhadap kegiatan makan dan minum di tempat umum. Kebijakan PPKM tersebut diharapkan adanya penekanan terhadap kasus covid-19 kehidupan ekonomi, sosial bisa berjalan normal seperti sediakala.

Realitas berbanding terbalik. Kebijakan penutupan pusat perbelanjaan di masa penerapan pembatasan kegiatan masyarakat (PPKM) darurat sejak 3 Juli hingga perpanjangan per level membuat para pedagang di Kebumen tidak bisa berjualan dan merugi. Pandemi Covid-19 hingga saat ini menyebabkan banyak pedagang yang mengalami kendala seperti sepinya pembeli akibat banyak penutupan jalan, penurunan omzet, bahkan tidak ada masukan sama sekali akibat tidak ada pembeli yang datang. Para pedagang akhirnya kesulitan untuk membiayai operasional sehari-hari dan tidak sedikit yang terpaksa menutup usahanya. Artinya kondisi tersebut mengakibatkan terganggunya sistem keluarga dan menggerus ketahanan keluarga.

Padahal, ketahanan keluarga perlu dijalankan oleh semua lini masyarakat yang telah berkeluarga. Karena merupakan tolok ukur pelaksanaan peranan, fungsi, tugas dan tanggung jawab sebuah keluarga dalam mewujudkan kesejahteraan anggotanya (Sunarti, 2006). Namun tidak dipungkiri di masa pandemi, banyak orang yang sudah berkeluarga di Indonesia sulit untuk memenuhi ketahanan keluarga dalam menjamin kebutuhan keluarga khususnya para pedagang (Tawakal et al, 2021). Research yang dilakukan oleh (Pramita, Muhlisin, \& Maleha 2021) menemukan efek pandemi covid dan kebijakan PPKM menyebabkan pedagang mengalami penurunan omzet, penurunan pendapatan bahkan menutup usahanya. (Djafar 2020) menemukan bahwa masa pandemi Covid-19 menyebabkan sepinya pembeli, meningkatnya penawaran perdagangan produk pertanian, yang pada akhirnya menurunkan harga yang merugikan pedagang, terutama mereka yang juga petani. Dampak diterapkanya kebijakan PPKM di masa pandemi menyebabkan turunnya omzet penjualan, terkendalanya distribusi bahan baku, serta merubah mindset masyarakat dari $B 2 B$ behavior menjadi business to customer dengan meningkatkan konversi dalam digital marketing (Pawłowski \& Pastuszak, 2016; Rizal, Afrianti, \& Abdurahman, 2021). Sementara itu, Hanoatubun (2020) menemukan efek kebijakan PPKM menyebabkan penutupan pasar. Hal ini mengakibatkan pedagang tidak mempunyai penghasilan tetap dan sulit untuk memenuhi kebutuhan hidupnya. Sejalan dengan temuan Sinaga \& Purba (2020); Sinaga \& Purba (2020); Azimah et al., (2020) pandemi Covid-19 berakibat terhadap turunnya daya beli masyarakat, sehingga terjadi kerugian dalam bidang ekonomi maupun sosial sehingga pedagang juga tidak bisa balik modal.

Artinya, Pandemi Covid-19 merupakan welfare emergency, dimana darurat kesehatan akibat Covid-19 juga telah mengakibatkan darurat ekonomi. Untuk itu, penanganan Covid-19 dari sisi ekonomi dan kesehatan harus dijalankan secara harmonis dan beriringan berbasiskan hak asasi manusia. Seperti temuan Susanto \& Asmara (2020), mendukung kebijakan PPKM yang perlu diambil dalam rangka membatasi pergerakan 
masyarakat guna mencegah penularan Covid-19, karena baik ekonomi maupun kesehatan merupakan hak asasi manusia yang tidak dapat dibagi (indivisibility), saling bergantung (interdependent), saling terkait (interrelated), dan tidak dicabut (inalienable). Dengan berpegang pada prinsip "salus populi suprema lex esto" keselamatan rakyat merupakan hukum tertinggi (Powell, 2006). Maka kebijakan kesehatan dalam rangka penyelamatan, pencegahan, maupun penyembuhan dari Covid19 harus menjadi prioritas pertama (Arde-Acquah, 2015). Dengan demikian ketahanan fisik masyarakat akan tetap terjaga dan ketahanan ekonomi akan pulih.

Penelitian ini bertujuan mengetahui sejauh mana ketahanan keluarga pedagang di Kebumen dilihat dari sisi ketahanan fisik, ketahanan ekonomi, ketahan sosial-psikolgis keluarga pedagang akibat pandemi Covid-19. Penelitian ini mencoba melengkapi berbagai kajian tentang pengaruh covid-19 yang sebagian besar mengungkapkan terkait efek terhadap ekonomi, serta melengkapi penelitian sebelumnya terkait ketahanan keluarga yang sebagian besar hanya dianalisis dalam satu indiKator sekaligus menjadi pembeda dengan penelitian sebelumnya. Lokasi penelitian di Kebumen dengan sampel dari 20 pasar dan lokasi perbelanjaan dan Kebumen merupakan daerah dengan level assesmen 4 dan menjadi zona merah Covid-19 (Jatengprof, 2021) atau memiliki risiko tinggi penularan virus corona (Kompas, 2021).

Ketahanan keluarga dalam penelitian ini dianalisis dengan tiga indikator yaitu dengan ketahanan fisik, ketahanan ekonomi dan ketahanan sosial-psikologis. Sesuai buku Pembangunan Ketahanan Keluarga (BPS, 2016), ketahanan fisik merupakan kondisi kesehatan bagi seluruh anggota keluarga dan terbebas dari berbagai penyakit dan kelemahan. Kesehatan fisik anggota keluarga dipengaruhi oleh berbagai kondisi pemenuhan kebutuhan pangan yang sehat dan bergizi dalam jumlah yang cukup serta istirahat yang cukup dan nyaman. Ketahanan ekonomi keluarga digambarkan kemampuan keluarga dalam memenuhi berbagai kebutuhan keluarga untuk melangsungkan kehidupannya secara nyaman dan berkesinambungan. Kondisi keluarga yang nyaman akan terpenuhi apabila memiliki dan menenempati rumah yang layak, memiliki rumah sendiri, pendapatan yang cukup untuk kebutuhan sehari-hari, tersedianya biaya pendidikan bagi anggota keluarga, memiliki tabungan dalam jumlah yang memadai serta memiliki jaminan kesehatan berupa asuransi kesehatan dan sebagainya. Ketahanan sosial-psikologis tercermin dari kemampuan sebuah keluarga dalam menanggulangi berbagai masalah non-fisik seperti pengendalian emosi secara positif, konsep diri positif (termasuk terhadap harapan dan kepuasan), kepedulian suami terhadap istri dan kepuasan terhadap keharmonisan keluarga (Sunarti et al, 2021).

\section{Metode Penelitian}

Metode yang digunakan dalam penelitian ini menggunakan pendekatan kuantitatif dengan penelitian cross sectional. Pendekatan kuantitatif dipilih karena penelitian ini bertujuan untuk menguji hipotesis melalui teknik uji statistik dari data penelitian berupa angka-angka. Metode yang digunakan dalam penelitian ini ialah analisis deskriptif dan analisis regresi linear. Analisis deskriptif digunakan untuk menganalisis data dengan cara 
mendeskripsikan atau menggambarkan yang telah dikumpulkan sesuai dengan apa yang ada tanpa bermaksud untuk memberikan kesimpulan yang berlaku umum atau generalisasi. Analisa ini dilakukan dengan cara menganalisa permasalahan tanpa mempergunakan perhitungan angka-angka tetapi menggunakan sumber-sumber informasi yang relevan seperti menggunakan buku, jurnal, dan literatur-literatur lainnya yang dibutuhkan.

Model analisis regresi linear dengan menggunakan metode kuadrat kecil (ordinary least square/ OLS) untuk melihat pengaruh beberapa variabel independen terhadap variabel dependen (S Ghozali, 2011). Langkah-langkah yang digunakan dalam mengukur model dalam penelitian ini meliputi melakukan uji validitas, uji reliabilitas, uji asumsi klasik, uji beda F, uji koefisien determinasi (R-Square), dan uji beda T. Analisis data dilakukan dengan menggunakan software SPSS. Analisis regresi linear berganda digunakan untuk mengetahui realitas ketahanan keluarga pedagang di masa pandemi covid-19. Ketahanan keluarga pedagang sebagai variabel dependen yang diproksikan mealui indikator ketahanan rumah tangga di Indonesia yaitu ketahanan fisik, ketahan ekonomi, ketahan sosial psikologis. Variabel Independen dalam penelitian ini ialah Pandemi Covid-19.

Berdasarkan uraian di atas, persamaan regresi linier berganda dalam penelitian ini dapat ditulis sebagai berikut:

$Y 1=\propto+\beta X+e$

Dimana $Y 1$ adalah ketahanan Fisik keluarga, $\propto$ is constant, $\beta$ is coefficient, $X$ adalah covid-19 and $e$ is error.

$Y 2=\propto+\beta X+e$

Dimana $Y 2$ adalah ketahanan ekonomi keluarga pedagang, $\alpha$ is constant, $\beta$ is coefficient, $X$ adalah covid-19 and $e$ is error.

$Y 3=\propto+\beta X+e$

Dimana $Y 3$ adalah ketahanan sosial-psikologis keluarga pedagang, $\propto$ is constant, $\beta$ is coefficient, $X$ adalah covid-19 and $e$ is error.

\section{Conceptual framework}

Penelitian ini mencoba mengetahui pengaruh Covid-19 terhadap ketahanan keluarga para pedagang di kebumen. Hypotesis penelitian ini dapat diilustrasikan dalam gambar 1. berikut: 


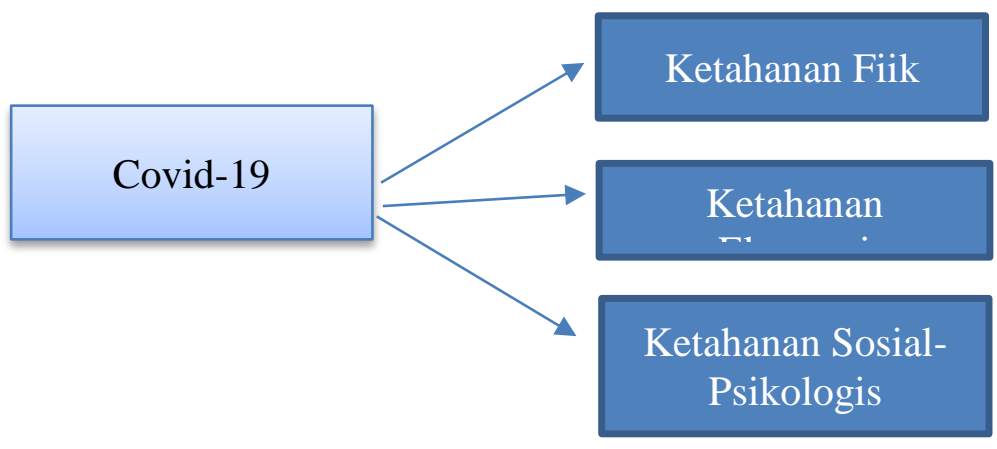

\section{Sampling}

Data yang digunakan dalam penelitian ini ialah data primer, karena peneliti mengambil atau mengumpulkan data secara langsung. adapun populasi penelitian ini adalah seluruh pedagang di kebumen. Teknik pengambilan sampel acak digunakan untuk mendapatkan responden dari kalangan pedagang yang terdampak covid-19. Kuesioner dibagikan secara online menggunakan formulir Google Form dan offline menggunakan angket kepada populasi yang telah ditentukan sebelumnya. Dari pilot study penyebaran pada 17 sampai 24 Juni 2021 diperoleh 150 responden. Setelah dilakukan uji validitas dan reliabilitas dilakukan mengurangi sejumlah pertanyaan yang tidak valid dan reliabel. Setelah dilakukan perbaikan kuesioner, kemudian pada tanggal 25 Juni-17 Juli 2021 dilakukan penyebaran kuesioner melalui sejumlah group Whatsapp (WA), terjun ke pasar, pertokoan dan area perdagangan. Hasil penyebaran kuesioner selama 21 hari diperoleh 200 responden dari 20 area perdagangan di kebumen yang terdiri dari pasar tradisional dan market place. Peneliti mengeliminasi 19 responden setelah mempertimbangkan kelengkapan informasi dari 200 responden. Akhirnya, diperoleh 181 responden telah memenuhi kelengkapan informasi.

\section{Hasil dan Pembahasan \\ Hasil}

\begin{tabular}{|c|c|c|c|c|c|}
\hline \multirow[t]{2}{*}{ Variabel } & \multicolumn{3}{|c|}{ Minimu } & \multirow[b]{2}{*}{ Mean } & \multirow[b]{2}{*}{ Std. Deviation } \\
\hline & $\mathrm{N}$ & $\mathrm{m}$ & Maximum & & \\
\hline PPKM & 181 & 40 & 81 & 63.62 & 9.402 \\
\hline Ketahanan Fisik & 181 & 4 & 16 & 10.17 & 3.286 \\
\hline Ketahanan Ekonomi & 181 & 9 & 28 & 17.23 & 4.998 \\
\hline $\begin{array}{l}\text { Ketahanan Sosial- } \\
\text { Psikologis }\end{array}$ & 181 & 4 & 12 & 8.35 & 2.036 \\
\hline
\end{tabular}

Tabel 1. Statistik Deskriptif

Explanation: $\mathrm{N}=\mathrm{jumlah}$ observasi

Analisis statistik deskriptif digunakan untuk mengetahui deskripsi data dari variabel. Berdasarkan Tabel 1, dapat diketahui deskripsi statistik dari variabel-variabel 
yang digunakan dalam penelitian ini. Untuk variabel PPKM jumlah data 181, nilai minimum 40, nilai maksimum 81, nilai rata-rata 63.62, dan standar deviasi 9.402. Untuk variabel ketahanan fisik jumlah data 181 , nilai minimum 4 , nilai maksimum 16 , nilai ratarata 10.17, dan standar deviasi 3.286. Untuk variabel ketahanan ekonomi jumlah data 181, nilai minimum 9, nilai maksimum 28, nilai rata-rata 17.23, dan standar deviasi 4.998. Adaun variabel ketahanan sosial-psikologis jumlah data 181, nilai minimum 4, nilai maksimum 12, nilai rata-rata 8.35, dan standar deviasi 2.036 .

Tabel 2. Hasil Analisis Regresi Model 1

\begin{tabular}{lllr}
\hline \multicolumn{1}{c}{ Variabel } & $B$ & $\beta$ & \multicolumn{1}{l}{ Sig. } \\
\hline Constant & 24.351 & & $0.000^{* *}$ \\
\hline PPKM $(\mathrm{X})$ & -0.223 & -0.638 & $0.000^{* *}$ \\
\hline Adjusted $\mathrm{R}^{2}$ & & & 0.404 \\
\hline
\end{tabular}

Explanation: Dependent Variable=Ketahanan Fisik, $\mathrm{B}=$ unstandardized coefficients, $\beta=$ standardized coefficients; Sig = significance; *significant on $\mathrm{p}<0,05 ; * *$ significant on $\mathrm{p}<0,01$.

Berdasarkan Tabel 2, nilai signifikansi dari variabel PPKM $<0,05$ yakni $0,000<$ 0,05. Sehingga Ho ditolak dan Ha diterima. Hal tersebut berarti bahwa terdapat pengaruh yang signifikan dari variabel PPKM terhadap variabel Ketahanan Fisik. Pengaruhnya bersifat negatif karena nilai koefisien dari variabel PPKM adalah -0.223. Sehingga dapat diartikan bahwa, jika variabel PPKM meningkat 1 satuan, maka variabel Ketahanan Fisik akan menurun sebesar 0.223 satuan. Di samping itu, jika nilai variabel PPKM adalah 0 maka nilai dari variabel Ketahanan Fisik adalah 24.351 satuan, hal tersebut dilihat dari nilai konstantanya. Oleh karenanya dapat dirumuskan model 1 dalam penelitian ini sebagaimana berikut:

Ketahanan Fisik $=24.351-0.223$ PPKM

Adapun nilai Adjusted $\mathrm{R}^{2}$ dalam model 1 adalah sebesar 0.404 yang berarti bahwa variasi dari variabel PPKM dapat menjelaskan variasi dari variabel Ketahanan Fisik sebesar $40.4 \%$, sedangkan sisanya dijelaskan oleh variasi variabel lain di luar model 1 .

Tabel 3. Hasil Analisis Regresi Model 2

\begin{tabular}{lllr}
\hline \multicolumn{1}{c}{ Variabel } & $B$ & $\beta$ & \multicolumn{1}{c}{ Sig. } \\
\hline Constant & 40.291 & & $0.000^{* *}$ \\
\hline PPKM $(\mathrm{X})$ & -0.362 & -0.682 & $0.000^{* *}$ \\
\hline Adjusted $\mathrm{R}^{2}$ & & & 0.462 \\
\hline
\end{tabular}


Explanation: Dependent Variable=Ketahanan Ekonomi, $\mathrm{B}=$ unstandardized coefficients, $\beta=$ standardized coefficients; Sig = significance; *significant on $\mathrm{p}<0,05 ; * *$ significant on $\mathrm{p}<0,01$.

Berdasarkan Tabel 3, nilai signifikansi dari variabel PPKM $<0,05$ yakni $0,000<$ 0,05. Sehingga Ho ditolak dan Ha diterima. Hal tersebut berarti bahwa terdapat pengaruh yang signifikan dari variabel PPKM terhadap variabel Ketahanan Ekonomi. Pengaruhnya bersifat negatif karena nilai koefisien dari variabel PPKM adalah -0.362. Sehingga dapat diartikan bahwa, jika variabel PPKM meningkat 1 satuan, maka variabel Ketahanan Ekonomi akan menurun sebesar 0.362 satuan. Di samping itu, jika nilai variabel PPKM adalah 0 maka nilai dari variabel Ketahanan Ekonomi adalah 40.291 satuan, hal tersebut dilihat dari nilai konstantanya. Oleh karenanya dapat dirumuskan model 2 dalam penelitian ini sebagaimana berikut:

Ketahanan Ekonomi $=40.291-0.362$ PPKM

Adapun nilai Adjusted $\mathrm{R}^{2}$ dalam model 2 adalah sebesar 0.462 yang berarti bahwa variasi dari variabel PPKM dapat menjelaskan variasi dari variabel Ketahanan Ekonomi sebesar 46.2\%, sedangkan sisanya dijelaskan oleh variasi variabel lain di luar model 2.

Tabel 4. Hasil Analisis Regresi Model 3

\begin{tabular}{lcrr}
\hline \multicolumn{1}{c}{ Variabel } & $B$ & $\beta$ & \multicolumn{1}{c}{ Sig. } \\
\hline Constant & 9.849 & & $0.000^{* *}$ \\
\hline PPKM $(\mathrm{X})$ & -0.024 & -0.109 & 0.124 \\
\hline Adjusted $\mathrm{R}^{2}$ & & & 0.007 \\
\hline $\begin{array}{l}\text { Explanation: } \\
\text { B=unstandardized coefficients, } \beta=\text { standardized coefficients; Sig = significance; }\end{array}$ \\
* significant on $\mathrm{p}<0,05 ; * *$ significant on $\mathrm{p}<0,01$.
\end{tabular}

Berdasarkan Tabel 4, nilai signifikansi dari variabel PPKM > 0,05 yakni $0.124>$ 0,05. Sehingga Ho diterima dan Ha ditolak. Hal tersebut berarti bahwa variabel PPKM tidak signifikan dalam mempengaruhi variabel Ketahanan Sosiologis-Psikologis. Selain itu, nilai Adjusted $\mathrm{R}^{2}$ dalam model 3 sangat kecil yakni 0.007 yang berarti bahwa hanya $0.7 \%$ saja variasi dari variabel PPKM mampu menjelaskan variasi dari variabel Ketahanan Sosiologis-Psikologis.

\section{Pembahasan}

Kebijakan PPKM berpengaruh negatif signifikan terhadap ketahanan fisik keluarga pedagang. Temuan ini sesuai dengan temuan Aisyah, (2020) dampak covid-19 dan kebijakan PPKM memang menekan penyebaran virus covid-19 namun meningkatkan angka kemiskinan serta relatif tingginya harga pangan. Kondisi tersebut memicu terjadinya kerawanan pangan dan ketahanan pangan keluarga, ketidaksanggupan membeli bahan pangan bergizi seimbang yang berpengaruh bagi ketahanan imun tubuh 
(Buana, 2020). Lebih dari itu, kebijakan PPKM darurat dengan berbagai level mengikis aktivitas produksi bahkan terhenti (Tarigan, Sinaga, \& Rachmawati, 2020). Sehingga distribusi pangan menjadi lemah. Akibatnya, stok pangan tidak merata di semua daerah (Afriza, Rachman, Abdullah, \& Nirbita, 2021). Ada daerah yang mengalami defisit dan ada pula yang mengalami produksi berlebih (Jusriadi, Mm, Kamaluddin, \& Aljurida, 2020). Situasi tersebut mengakibatkan prevalensi ketidakcukupan konsumsi pangan (prevalence of undernourishment) terus menurun, semakin tingginya kelebihan berat badan (overweight) dan obesitas, serta defisiensi mikronutrien (micronutrient deficiency) (Arif, Isdijoso, Fatah, \& Tamyis, 2020). Semakin diperpanjangnya kebijakan Pembatasan Kegiatan Masyarakat (PPKM) Darurat semakin berdampak signifikan bagi pemenuhan kebutuhan pangan dan gizi masyarakat Indonesia (A'dani, Sukayat, Setiawan, \& Judawinata, 2021). Pada akhirnya pola konsumsi sebagian besar masyarakat Indonesia masih kurang ideal, dengan karbohidrat masih mendominasi asupan kalori; konsumsi protein, buah-buahan, dan sayuran masih belum mencukupi; serta peningkatan konsumsi makanan olahan dan siap saji di perkotaan maupun perdesaan. Hal tersebut memberikan beban malnutrisi, yaitu gizi kurang yang berdampingan dengan kelebihan gizi (overnutrition) dan defisiensi mikronutrien, prevalensi stunting, berat badan kurang (underweight), dan wasting.

Kebijakan PPKM berpengaruh negatif signifikan terhadap ketahanan ekonomi keluarga pedagang. Temuan ini sejalan dengan temuan Rizal et al., (2021) kebijakan PPKM berdampak terhadap pendapatan pedagang, distribusi barang, menurunnya daya beli masyarakat. Pedagang merasa tidak termotivasi untuk meningkatkan produktivitasnya (Sutedjo \& Murtini, 2021). Mengakibatkan pedagang tidak mampu mempertahankan pembeli, kehilangan pendapatan, ketidakmampuan membeli bahan baku dan terpaksa menutup usahanya (Pramita et al., 2021). Terlebih kebijakan PPKM menuntut dalam pemenuhan kebutuhan gadget dan kuota internet dalam sebulan penuh demi melangsungkan pembelajaran atau sekolah anak dari rumah (Ristyawati, 2020). Kondisi tersebut pada akhirnya menggerus pertahanan ekonomi keluarga pedagang yang disebabkan oleh persoalan ekonomi (Tawakal et al., 2021). Artinya fungsi ekonomi memiliki peranan penting dalam sebuah keluarga, karena ketahanan keluarga akan diuji ketika terjadi kesulitan dalam pemenuhan kebutuhan pangan. Selanjutnya temuan Zulhijahyanti et al., (2021) dalam rangka menjaga ketanan ekonomi keluarga, pedagang sebaiknya mengganti strategi pemasaran yang digunakan dari offline menjadi online seperti penggunaan media sosial, serta tergabung dalam usaha online lainnya seperti shopee, go-food, dan grab-food. Sejalan dengan temuan Amri (2020), dalam mempertahankan ketahanan ekonomi, pedagang dapat melakukan digitalisasi pemasaran dengan strategi refokus pelanggan dan industri rethinking, merancang strategi sosial dan digital dan mengembangkan kapabilitas organisasi.

Kebijakan PPKM di lain pihak tidak berpengaruh terhadap ketahanan sosialpsikologi keluarga pedagang di Kebumen. Temuan tersebut sejalan dengan temuan Tawakal et al., (2021), tergerusnya ketahanan ekonomi tidak serta merta menggerus ketahanan sosial-psikologis keluarga pedagang, tentunya mereka merasa kesulitan namun 
tetap berpsinsip pada kesabaran, ikhtiar, menjaga kesehatan, melakukan pendampingan pembelajaran daring anak dengan sabar dan saling membantu dengan warga sekitar. Semakin tinggi rasa memiliki satu sama lain maka akan meningkatkan ketahanan sosial psikologi keluarga maupun sebuah komunitas (Sunarno \& Sulistyowati, 2021). Sehingga memunculkan nilai sosial seperti gotong royong, musyawarah, dan keselarasan dengan alam. Secara alamiah membentuk perilaku sosial seperti kepatuhan, dan ketetanggan yang prososial dan mampu mendukung untuk bertahan di masa pandemic covid-19. Pada akhirnya akan berimplikasi pada ketahanan keluarga dan ketahanan masyarakat dalam lingkup luas (Michalski et al, 2020).

\section{Kesimpulan}

Pandemi Covid-19 yang berjalan lebih dari 2 tahun di seluruh wilayah Indonesia yang berdampak dari berbagai sisi kehidupan masyarakat mengharuskan pemerintah mengambil kebijakan. Berdasarkan surat edaran No 11 tahun 2021 pemerintah menerapkan Pemberlakukan Pembatasan Kegiatan Masyarakat Darurat dan Pembatasan Kegiatan Bepergian ke Luar Daerah dan Atau Cuti Libur Nasional Selama Masa Pandemi tahun 2021. Kebijakan tersebut diambil dalam rangka penekanan angka penyebaran virus corona-19. Walaupun di lain pihak kurang setuju dengan alasan darurat pengambilan kebijakan PPKM. Alasanya akan menimbulkan dampak terhadap sosial dan ekonomi di Indonesia. Tidak dipungkiri kebijakan PPKM tersebut memberikan pengaruh negatif signifikan terhadap ketahanan fisik dan ekonomi keluarga pedagang di Kebumen, namun tidak berpengaruh terhadap ketahanan sosial psikologis. Nilai-nilai sosial yang internalisasi kuat dalam masyarakat mendukung ketahanan sosial-psikologis yang diduga akan terpengaruh dengan menurunya ketahanan fisik dan ekonomi pedagang di Kebumen.

Kebijakan PPKM Darurat di Jawa-Bali ini tidak hanya didasarkan pertimbangan kesehatan semata, namun juga mempertimbangkan ekonomi dan sosial. Bahkan sering kali kebijakan-kebijakan terkait Covid-19 lebih sarat dengan kepentingan politik dibanding kepentingan kesehatan. Kepentingan politik dapat dilihat dari sejumlah aturan pelanggaran protokol kesehatan tidak berlaku secara konsisten di beberapa daerah, tidak tegasnya kebijakan terhadap tenaga asing di masa PPKM darurat, kebijakan PKH dan program perlindungan sosial yang tidak tepat sasaran, kebijakan terhadap ketersediaan pangan.

Finally, penelitian ini terbatas hanya menggambarkan ketahanan fisik, ekonomi, dan sosial-psikologi pedagang di Kebumen. Penelitian berikutnya diharapkan memasukan ketahanan sosial budaya pedagang dengan cakupan yang lebih luas atau jangkauan nasional. Serta memasukan unsur politik dalam pengambilan kebijakan Covid19. 
Apakah Kebijakan Pemberlakuan Pembatasan Kegiatan Masyarakat Darurat (PPKM)

Berpengaruh Terhadap Ketahanan Keluarga Pedagang di Kebumen

\section{Bibliografi}

A'dani, Fatihah, Sukayat, Yayat, Setiawan, Iwan, \& Judawinata, M. Gunardi. (2021). Pandemi Covid-19: Keterpurukan Dan Kebangkitan Pertanian Strategi Mempertahankan Ketersediaan Pangan Pokok Rumah Tangga Petani Padi Pada Masa Pandemi Covid-19. Mimbar Agribisnis: Jurnal Pemikiran Masyarakat Ilmiah Berwawasan Agribisnis, 7(1), 309-319.

Afriza, Edi Fitriana, Rachman, Andi Nur, Abdullah, Fuad, \& Nirbita, Betanika Nila. (2021). Piloting Penanggulangan Krisis Pangan Pada Masa Pandemi Covid-19 Melalui Optimalisasi Kawasan Rumah Pangan Lestari di Kelurahan Mugarsari dan \begin{tabular}{lllll}
\hline Setiawargi Kota & Tasikmalaya. & Jattec, & 2(1),
\end{tabular} https://doi.org/https://doi.org/10.20885/jattec.vol2.iss1.art6

Aisyah, Iseu Siti. (2020). Ketahanan Pangan Keluarga di Masa Pandemi Covid-19. Jurnal Kesehatan Komunitas Indonesia, 16(2), 179-189.

Amri, Andi. (2020). Dampak Covid-19 terhadap UMKM di Indonesia. Jurnal Brand, 2(1), 123-120.

Arde-Acquah, Phoebe E. (2015). Salus Populi Suprema Lex Esto: Balancing Civil Liberties and Public Health Interventions in Modern Vaccination Policy. Washington University Jurisprudence Review, 7(2), 337.

Arif, Sirojudin, Isdijoso, Widjajanti, Fatah, Akhmad Ramadhan, \& Tamyis, Ana Rosidha. (2020). Tinjauan Strategis Ketahanan Pangan dan Gizi di Indonesia: Informasi Terkini 2019-2020. Indonesia.

Azimah, Rizki Nor, Khasanah, Ismi Nur, Pratama, Rizki, Azizah, Zulfanissa, Febriantoro, Wahyu, \& Pornomo, Shafa Rifda Syafira. (2020). Analisis dampak Covid-19 terhadap sosial ekonomi pedagang di pasar klaten dan wonogiri. EMPATI: Jurnal Ilmu Kesejahteraan Sosial, 9(1), 59-68. https://doi.org/10.15408/empati.v9i1.16485

BPS. (2016). Pembangunan Ketahanan Keluarga (2006th ed.; M. Si. Dwi Retno Wilujeng Wahyu Utami, S.Si., Editor, M. Si. : Dwi Retno Wilujeng Wahyu Utami, S.Si., M. A. Krismawati, M. A. Krismawati, M. A. Dra. Lieska Prasetya, M.Sc. Karmaji, SE., M. Sc. Dra. Lieska Prasetya, M. Si. Puji Lestari, S.Si., M. A. Karmaji, SE., M. Si. Diana Aryanti, S.P., S. S. M. Si. Puji Lestari, S. Si. Armi Susilowati, M. Si. Diana Aryanti S.P, Drs. Sayuti Fitri, S. Si. Armi Susilowati, M. M. Skriptandono, SE., Drs. Sayuti Fitri, S. Sos. Dwi Ratna Anugerah, M. M. Skriptandono, SE., SE. Sr Di Lestari, \& wi Ratna An, eds.). Jakarta: Badan Pusat Statistik.

Buana, Dana Riksa. (2020). Analisis Perilaku Masyarakat Indonesia dalam Menghadapi Pandemi Virus Corona (Covid-19) dan- Kiat Menjaga Kesejahteraan Jiwa. Salam Jurnal Sosial Dan Budaya Syar'i, 7(3), 217-226.

Djafar, Fariastuti. (2020). Dampak Covid-19 Terhadap Pedagang Produk Pertanian di Perbatasan Kalimantan Barat - Sarawak. Prosiding Seminar Akademik Tahunan 
Ilmu Ekonomi Dan Studi Pembangunan, 260-265. Pontianak: Universitas Tanjung Pura.

Hanoatubun, Silpa. (2020). Dampak Covid-19 Terhadap Perekonomian Indonesia. EduPsyCouns: Journal of Education, Psychology and Counseling, 2(1), 146-153.

Jusriadi, A., Mm, S. T., Kamaluddin, Laode Amijaya, \& Aljurida, A. M. Azhar. (2020). Food Crisis Mitigation Management in The Covid Pandemic Era 19. Journal of Governance and Local Politics (JGLP), 2(2), 216-227. https://doi.org/https://doi.org/10.47650/jglp.v2i2.96

Michalski, Camilla A., Diemert, Lori M., Helliwell, John F., Goel, Vivek, \& Rosella, Laura C. (2020). Relationship between sense of community belonging and self-rated health across life stages. SSM - Population Health, 12(6), 100676. https://doi.org/10.1016/j.ssmph.2020.100676

Pawłowski, Mieczysław, \& Pastuszak, Zbigniew. (2016). B2B Customers Buying Behavior. International Journal of Synergy and Research, 5(9), 19-35. https://doi.org/10.17951/ijsr.2016.5.19

Pramita, Cindi, Muhlisin, \& Maleha, Nova Yanti. (2021). Dampak Covid-19 Terhadap Pendapatan Pedagang-Pedagang Kecil di Kantin Universitas Indo Global Mandiri Palembang. Jimesha, 1(1), 69-74. https://doi.org/10.36908/Jimesha

Ristyawati, Aprista. (2020). Efektifitas Kebijakan Pembatasan Sosial Berskala Besar Dalam Masa Pandemi Corona Virus 2019 oleh Pemerintah Sesuai Amanat UUD NRI Tahun 1945. Administrative Law \& Governance Journal., 3(2), 240-249. https://doi.org/https://doi.org/10.14710/alj.v3i2.240-249

Rizal, Muhammad, Afrianti, Ria, \& Abdurahman, Iman. (2021). Dampak Kebijakan Pemberlakuan Pembatasan Kegiatan Masyarakat ( PPKM ) bagi Pelaku Bisnis Coffe shop pada Masa Pandemi Terdampak COVID-19 di Kabupaten Purwakarta. Jurnal Inspirasi, 12(1), 96-105. https://doi.org/https://doi.org/10.35880/inspirasi.v11i1.198 Dampak

Sinaga, Robert, \& Purba, Melfrianti Romauli. (2020). Pengaruh Pandemi Virus Corona (Covid-19) Terhadap Pendapatan Pedagang Sayur Dan Buah Di Pasar Tradisional "Pajak Pagi Pasar V" Padang Bulan. Regionomic, 2(02), 37-48.

Sunarno, \& Sulistyowati, Endang. (2021). Resiliensi komunitas di tengah pandemi Covid-19. Mediapsi, 7(1), 37-52. https://doi.org/http://dx.doi.org/10.21776/ub.mps.2021.007.01.5

Sunarti, Euis. (2006). Indikator Keluarga Sejahtera: Sejarah Pengembangan, Evaluasi, dan Keberlanjutannya. Bogor: Fakultas Ekologi Manusia.

Sunarti, Euis, Rizkillah, Risda, Hakim, Fitri Apriliana, Zakiya, Nova, \& Damayanti, Rahmi. (2021). Manajemen sumber daya keluarga, konflik kerja-keluarga, dan tugas 
Apakah Kebijakan Pemberlakuan Pembatasan Kegiatan Masyarakat Darurat (PPKM)

Berpengaruh Terhadap Ketahanan Keluarga Pedagang di Kebumen

keluarga. Jurnal Ilmu Keluarga Dan Konsumen, 14(1), 1-13. https://doi.org/DOI: http://dx.doi.org/10.24156/jikk.202 1 .1 4 .1.1

Susanto, M., \& Asmara, T. T. P. (2020). EKONOMI VERSUS HAK ASASI MANUSIA DALAM PENANGANAN COVID-19: DIKOTOMI ATAU HARMONISASI (The Economy versus Human Rights In ... Jurnal Ham, 11(2), 301-307. https://doi.org/DOI: http://dx.doi.org/10.30641/ham.2020.11.301-317

Sutedjo, Agus, \& Murtini, Sri. (2021). Dampak pandemi covid-19 terhadap kondisi sosial ekonomi pedagang keliling di kelurahan Kedurus. Jurnal Geografi Dan Pengajaranya, XIX(1), 25-34.

Tarigan, Herlina, Sinaga, Juni H., \& Rachmawati, Rika R. (2020). Dampak Pandemi Covid-19 Terhadap Kemiskinan di Indonesia. Pusat Sosial Ekonomi Dan Kebijakan Pertanian, (3), 457-479.

Tawakal, Andri Amin, Lakuanine, Ahmad Budi, Zikry, Farhan, Hudafi, Hamsah, \& Basri, Ahmad Hasan. (2021). Ketahanan Keluarga Pedagang Kaki Lima dalam Pemenuhan Kebutuhan di Masa Pandemi; Studi Lapangan Pedagang Kaki Lima Di Sekitar Kampus UIN Sunan Kalijaga. SALAM: Jurnal Sosial Dan Budaya Syar-I, 8(4), 1037-1050. https://doi.org/10.15408/sjsbs.v8i4.20940

Zulhijahyanti, Hanna, Ayu, Kintan, Safira, Agnes, Saputri, Leonita Lisha, \& Permana, Erwin. (2021). Strategi mempertahankan usaha pedagang kaki lima (PKL) di masa pandemi Covid-19. Inovasi Jurnal Ilmiah Ilmu Manajemen, 8(1), 21-29. https://doi.org/http://dx.doi.org/10.32493/Inovasi.v8i1.p21-29.11490 